«Keruen» scientific journal

M.O.Auezov Institute of Literature and Art

ISSN 2078-8134

Volume 72, Number 3 (2021)

IRSTI 17.07.61

https://doi.org/10.53871/2078-8134.2021.3-07

\title{
M.O. Shagimoldina
}

M.O. Auezov Institute of Literature and Art

Almaty, Kazakhstan

E-mail: marzhanshagimoldina@gmail.com

ORCID: 0000-0002-0784-640X

\section{PROBLEMS OF TRANSLATION OF WORKS OF KAZAKH POETS AND WRITERS INTO FOREIGN LANGUAGES}

\begin{abstract}
The article examines the general and specific aspects of the issues of literary translation from Kazakh literature into a foreign one, the possibilities of bringing the translated text closer to the original, achievements and shortcomings in this area, their causes. The question of observing a literary linguistic text and reproducing it in another language has long attracted the attention of translation practitioners and theorists, and various, sometimes contradictory, scientific views on this problem have been expressed. The issues of translation of the works of Kazakh writers into Russian and other languages are studied by philologists of Kazakhstan for a long period of time. However, every year there is an increasing need to systematize the available translations and publish generalizing studies. The issues of translation of literary texts of Kazakh writers into Russian and other languages are studied by philologists of the country for a long period of time. However, this topic is still relevant, since the problem of translating literary texts in Kazakh translation studies requires research.

Literary translation is considered one of the most difficult types of translation, and is also a kind of word-making art. Thus, the relevance of this article is due to the need to systematize the history of the formation and development of Kazakh translation studies. Among Western countries, France, Germany, Hungary, and the United States show the greatest interest in domestic literature. Among the countries of the foreign East are Turkey, the Republic of Korea, India, Pakistan, Iran, China, Mongolia. The largest number of researchers of the creativity of Kazakh writers and poets are represented by France, Germany, Pakistan, and Turkey. Artistic translations preserve and transmit the literary heritage of the post-Soviet period, which includes a variety of languages, traditions, and customs, and are also a connecting bridge between countries, transmitting the richness of culture and mentality of peoples. In fact, the artistic style is the area of functioning of various functional styles: conversational, official-business, journalistic, even scientific and technical. It is the dynamics of the forms of existence of various linguistic units and the alternation of forms that is particularly difficult in artistic translation.
\end{abstract}

Keywords: translation, Kazakh poets, Kazakh writers, works, literary translation.

Introduction. Among the many complex issues that are studied through modern linguistics, the field of mastering the linguistic aspects of the activity of interlinguistic relations, called "translation" or "translation service", occupies an important place. Translation is, of course, a very ancient form of human activity. In the history of mankind, along with the formation of groups of people with language differences, there have been "bilinguals" who help to communicate with "different language" groups. With the advent of the written language, such oral "correspondent-translators" began to be joined by translators who translated a variety of texts, as official, religious and business. From the very beginning, translation has served as a linguistic link between important social people. Distribution of written translations allowed people to expand their access to the cultural heritage of other peoples, to enrich and influence their culture and 
literature. Knowledge of foreign languages allows you to read the original books in those languages, but not everyone can master a single foreign language. [1]

The French humanist, explicit and translator Etienne Dole (1509-1546) argued that the translator should follow five basic principles of translation: 1. Free understanding of the content of the translated text and the purpose of the author; 2. Uniform knowledge of the languages of translation from which language to which language; 3. Abandonment of literal, exact translation, as this changes the content of the original and destroys its artistic form. 4. Use of commonly used forms of speech in translation; 5. Correct use and sequencing of words that have a general effect, going beyond the appropriate "rhythm" of the original. In 1790, in the English book "Principles of Translation" by A. Titler, the main requirements for translation are as follows: 1) the translation must fully convey the original idea; 2) the style and content of the translation should be the same as the original; 3) the translation, like the original work, should be easy to read. The scientific basis of translation was formed in the middle of the twentieth century, when the issue of translation came to the attention of journalists. Until then, the problem of translation was not considered in any way to the problems of linguistics. The translators themselves have argued that the linguistic aspects of translation play a small, purely technical role in the "art of translation". Of course, the translator must be fluent in the language of translation as well as the original language, but knowledge of languages is only an additional aspect of translation, not a basis. The role of such knowledge can be compared to the role of knowledge of notes for the composer. For their part, journalists did not intend to include translation in the object of linguistic research, but it was determined by linguistic factors. [1, p.6] Written translation is divided into two types: 1) Literary translation - the translation of works of fiction, i.e. texts whose main function is to have an artistic and aesthetic effect on the reader. The translator's possibilities in this process are endless; it can edit and edit text written in a second language. Literary or literary translation is the delivery of a literary work written in one language to the readers by means of another language and the most accurate preservation of the stylistic and artistic features of the original [2].

Methods. It is assumed that various methodological and theoretical approaches will be used. The research is based on the classification method aimed at systematization of empirical material, the method of comparative analysis, elements of the method of statistical data processing.

Results. Within the framework of the project "Modern Kazakhstani culture in the world" the work on introduction of modern poetry and prose to the world is carried out within the program "Spiritual revival". The best works of Kazakh literature were translated and presented in the leading languages of the world. An anthology of four volumes of prose and one volume of poetry has been translated into six UN languages: English, French, Spanish, Chinese, Arabic and Russian. The translation work was coordinated by the National Translation Bureau Public Foundation. Each book has a special creative team, which includes a translator, scientific editor, literary editor, editor-in-chief, designer, and proofreader. The creative team works closely and closely monitors the translation process. In the case of the need to introduce a new term in the translation, the opinion of leading scholars plays a key role. In addition, we pay close attention to the similarity of terms between books published in the same field. For this purpose, using special computer programs, the translated text is repeatedly checked by the literary and scientific editors, proofreaders. The book is then given to other scholars as an external source and reviewed again. Leading professors and practitioners of dozens of universities in Kazakhstan are involved in this work [4].

We need to pay attention to the problems that arise in translation today, for example, a translator, a writer and a blogger. According to Zaure Bataeva, a graduate of Almaty State University (KazNPU) and Indiana University (USA): "Literary editing in Kazakhstan is not well organized. We confuse the work of a proofreader with the work of an editor. Western publishing houses and publishers carefully edit each work with the author before publishing it. The work is not presented to the reader without inventory. This great work cannot be done by a writer alone. Therefore, Western publishers turn to a special editor. Their work is highly valued. We have a stagnant publishing business, so it's ridiculous to talk about it. It is a mistake to consider works 
published by the state as an achievement. That is, if the author's works do not bring him success, then it is better to talk about creativity. Such things as the state order, the mass surveillance of the works of writers in general - a real abuse of literature. In this case, neither language nor literature will develop." [5].

Discussion. A well-translated literary translation is one that grows along with the original works in that language and is inextricably linked. It acquaints the country with the country, brings them closer, and enriches the national culture. Here the author and the translator compete in art, language and language compete. It is an art competition of one country with another country. Therefore, translated works are a way to prove the greatness of the nation, the country as the country. Scientist A. Aldasheva suggests the following features of literary translation: a) literary translation - the fruit of the figurative type of thinking; therefore, there is an individual, creative search; but b) the scope of the search is limited, because the content structure in front of the translator does not allow the finished text to creative freedom; c) literary translation should have the same aesthetic function as the original literature; d) literary translation should be read as well as original literature; e) therefore, the translation must preserve the natural state of the Kazakh language, word usage, spelling norms [3, p. 26]. 2) Information translation - is the transfer of any information, data. Information translation itself is divided into the following types: - Scientific and technical translation includes scientific articles, monographs, and technical descriptions. Each industry has its own standard style, terminology, text structure.

In modern translation studies, there are five main criteria for assessing the quality of translation (of any type). First, the relevance of the content, the gaps in the content of the translation are considered factual errors, which greatly impairs its quality. Second, there are other requirements to the translation than the factual correspondence. The main thing is to comply with the rules and regulations of the language of translation. If there are language errors in the translated text (spelling - spelling, sentence construction - syntactic, word classification, morphological, word usage - lexical, etc.), such a translation is not considered satisfactory. Third, if the above two indicators are met, the quality of the original author will decrease if the communicative purpose of the original is not clear in the translation. Such gaps (if the main purpose of the author is slightly changed in the translation when the original is published) arise from the lack of understanding of the metaphorical meaning of some words, phrases, idioms and catchphrases, i.e. the national culture of the people who created the second language. Fourth, the translation should be neutral, humorous, sarcastic, etc. of the original language. It is advisable to keep the shade. To do this, you need to convey the connotations of the text. Fifth, the translation must retain the views of the author set out in the original, even if the translator does not agree with it. Otherwise, if the general idea of the text does not correspond to the original, and is slightly distorted, it cannot be considered a translation. These requirements, of course, are general, basic, and common to all types of translation. Specifically, communication through spoken language means that the speaker and the receiver communicate with each other during the speech and are influenced by the speech [6].

In Kazakhstan, the translation practice originated at the time of Kazakhstan's accession to Russia. At that time, the Institute of translation was actively developing at the source of their interrelation and interaction, and the interpreters and translators of Russia performed a huge amount of work. Translation of the works of Kazakh writers into Russian and other languages of the world has significantly expanded the understanding of the past of the Kazakhs, transforming the works of Kazakh literature into the language of other cultures. Medeubai Kurmanov made a great contribution to the development of the history of translation activity and translation tradition by translating Goethe's Faust into Kazakh for the first time. In the future, he was engaged in theoretical issues of translating German poetry and prose into Kazakh. The appearance of "Faust" in the Kazakh translation became an important event in the translation literature of Kazakhstan [7].

During this period, translators face a number of problems such as: 1) the reconstruction of the original Kazakh text in Russian, taking into account the difference in the systems of syllabics, tonics, genre specifics in the literary traditions of both languages; 2) the compilation of a 
hermeneutic commentary, including the literary tradition, everyday life, cultural and historical "origins" of the people; 3 ) the preservation of the national-historical flavor and originality of the original style [8]. A characteristic feature of the development of the Kazakh-language translation practice now is the appearance of direct translations from Kazakh into foreign languages (often with the involvement of native speakers) and from foreign languages into Kazakh.

Conclusion. The requirements for scholars and practitioners of the translator can be summarized as follows: 1 . He has a sufficient knowledge of the morphology, syntax, vocabulary, and idioms of the original language, as well as a deep understanding of their native language, bilingual system must be. 2 . It also consists of two main tasks: the correct understanding of the content of the target language and the accurate and complete delivery of that content by means of the target language. The translator accumulates his general knowledge and experience in the technical literature required for translation. By mastering the general information and always keeping it in mind, the translation contributes to the full quality of the version. For the translated version to function as aesthetically as the original, to create the same effect, the translator must be a person with lingua ethnic competence (lexical-structural system of the native language). Lingua ethnic competence requires a good command of the Kazakh language, i.e. the translator must be a person with a comprehensive set of speech, speech patterns, comprehension of whole language materials, thinking and psychological activity and cultural and ethnic characteristics of the main native language. To solve the problems of literary translation of works of art, we offer: 1) pay attention to the issues of translation from the substring, which were discussed more than once during the years of translation development in the Soviet era, but never found their solution. The so-called secondary translations provoke "interference" in the transmission of information; 2) the issue of training qualified personnel always remains in the center of attention of translation theorists. The identity of the translator is of great importance. When translating, he conveys his subjective point of view, his vision. Russian Russian translation from Kazakh to Russian, from Russian to Kazakh, has been developing quite a lot since ancient times. Translations from the Kazakh language to other foreign languages are still at the stage of development today, so this aspect should be paid attention to.

М.О. Шагимолдина

М.О.Әуезов атындағы Әдебиет және өнер институты

Алматы, Қазақстан

E-mail: marzhanshagimoldina@gmail.com

\section{ҚАЗАҚ АҚЫН-ЖАЗУШЫЛАРЫНЫН ШЫҒАРМАЛАРЫН ШЕТЕЛ ТІЛДЕРІНЕ АУДАРУ МӘСЕЛЕЛЕРІ}

Мақалада қазақ әдебиетінен шетел әдебиетіне көркем аударма мәселесінің жалпы және ерекше аспектілері, аударылған мәтінді түпнұсқаға жақындату мүмкіндіктері, осы саладағы жетістіктер мен кемшіліктер, олардың себептері зерттелген. Әдеби лингвистикалық мәтінді бақылау және оны басқа тілде шығару мәселесі бұрыннан бері аудармашылар мен теоретиктердің назарын аударып келеді, бұл мәселе бойынша әртүрлі, кейде қарама-қайшы, ғылыми көзқарастар айтылады. Қазақ жазушыларының көркем шығармаларын орыс және басқа тілдерге аудару мәселелерін Қазақстан филологтары ұзақ уақыт бойы зерттеп келеді. Алайда, жыл сайын бар аудармаларды жүйелеу және жалпылама зерттеулерді жариялау қажеттілігі артып келеді. Қазақ жазушыларының көркем мәтіндерін орыс тіліне және басқа тілдерге аудару мәселелерін ел филологтары ұзақ уақыт бойы зерттеп келеді. Дегенмен, бұл тақырып әлі де өзекті болып қала береді, өйткені қазақстандық аударма ғылымында көркем мәтіндерді аудару мәселесі зерттеуді қажет етеді.

Көркем аударма аударманың ең күрделі түрлерінің бірі болып саналады, сонымен қатар сөз жасау өнерінің бір түрі болып табылады. Осылайша, осы мақаланың өзектілігі қазақстандық аударматанудың қалыптасу және даму тарихын жүйелеу қажеттілігімен 
негізделген. Батыс елдерінің ішінде Франция, Германия, Венгрия және АҚШ отандық әдебиетке үлкен қызығушылық танытады. Шетелдік Шығыс елдері арасында Түркия, Корея Республикасы, Үндістан, Пәкістан, Иран, Қытай, Моңғолия бар.Қазақстан жазушылары мен ақындарының шығармашылығын зерттеушілердің ең көп саны Франция, Германия, Пәкістан және Түркия.Көркем аудармалар посткеңестік кезеңдегі тілдердің, дәстүрлер мен әдет-ғұрыптардың алуан түрлілігін қамтитын әдеби мұраны сақтайды және жеткізеді, сондай-ақ халықтардың мәдениеті мен менталитетінің байлығын жеткізетін елдер арасындағы байланыстырушы көпір болып табылады.Шын мәнінде, көркемдік стиль - бұл әртүрлі функционалды стильдердің қызмет ету саласы: сөйлеу, ресми бизнес, журналистік, тіпті ғылыми-техникалық. Бұл әр түрлі тілдік бірліктердің өмір сүру формаларының динамикасы және көркемдік аудармада ерекше қиындық тудыратын формалардың ауысуы.

Түйін сөздер: аударма, қазақ ақындары, қазақ жазушылары, шығармалар, көркем аударма.

\section{М.О. Шагимолдина}

Институт литературы и искусства им. М.О.Ауэзова

Алматы, Казахстан

E-mail: marzhanshagimoldina@gmail.com

\section{ПРОБЛЕМЫ ПЕРЕВОДА ПРОИЗВЕДЕНИИ КАЗАХСКИХ ПОЭТОВ И ПИСАТЕЛЕЙ НА ИНОСТРАННЫЕ ЯЗЫКИ}

В статье изучены общие и специфические аспекты вопросов художественного перевода с казахской литературы на иностранную, возможности приближения переводимого текста к оригиналу, достижения и недостатки в этой области, их причины. Вопрос о наблюдении за литературным лингвистическим текстом и его воспроизведении на другом языке давно привлекает внимание практиков и теоретиков перевода, высказываются различные, порой противоречивые, научные взгляды на эту проблему. Вопросы перевода художественных произведений казахских писателей на русский и другие языки изучаются филологами Казахстана в течение длительного периода времени. Однако с каждым годом возрастает потребность в систематизации имеющихся переводов и публикации обобщающих исследований. Вопросы перевода художественных текстов казахских писателей на русский и другие языки изучаются филологами страны в течение длительного периода времени. Однако данная тема все еще остается актуальной, так как проблема перевода художественных текстов в казахстанском переводоведении требует проведения исследований.

Художественный перевод считается одним из сложнейших видов перевода, а также является разновидностью искусства словотворчества. Таким образом, актуальность данной статьи обусловлена необходимостью систематизировать историю становления и развития казахстанского переводоведения. Среди западных стран наибольший интерес к отечественной литературе проявляют Франция, Германия, Венгрия, США. Среди стран зарубежного Востока - Турция, Республика Корея, Индия, Пакистан, Иран, Китай, Монголия. Самым большим числом исследователей творчества казахстанских писателей и поэтов представлены Франция, Германия, Пакистан и Турция. Художественные переводы сохраняют и передают литературное наследие постсоветского времени, вбирающее в себя многообразие языков, традиций и обычаев, а также являются связующим мостом между странами, передающим богатство культуры и менталитета народов. На самом деле, художественный стиль является областью функционирования различных функциональных стилей: разговорного, официально-делового, публицистического, даже научнотехнического. Именно динамика форм существования различных языковых единиц и чередование форм представляет особую трудность при художественном переводе. 


\section{Ключевые слова: перевод, казахские поэты, казахские писатели, произведения, художественный перевод.}

Информация об авторе: М.О. Шагимолдина, научный сотрудник Института литературы и искусства им. M.О.Ауэзова, Алматы, Казахстан. E-mail: marzhanshagimoldina@gmail.com, ORCID: 0000-0002-0784-640X

\section{References:}

[1]. Akhmetova,A.B. (2014). Audarma teorijasy men täzhiribesining negizderi [Basics of the theory and practice of translation]. Textbook of lectures. Pavlodar: PSPI, p. 90 [in Kazakh and Russian].

[2]. Temirbolat, A., Zhusupova, A., Shortanbaev, Sh. (2014). «XXI gasyrdagy philologija gylymy: mäselelri men bolashagy» atty khalyqaralyq gylymi phorum materialdary. [Materials of the international scientific forum "Philological science in the XXI century: problems and prospects"] Almaty: "Kazakh University", p.180. [3]. Aldasheva, A. (2008). Audarmatanu gylymynyng basty ugym-tusinikteri turaly [On the main concepts of the science of translation studies] // Translation studies (scientific and practical aid). Compiled by: Kulmanov S., Almaty: "Language" educational and methodical center, p. 26. (kz)

[4]. Bokenbaikyzy, B. “Bolashakka bagdar: Rukhani zhanggyru” bagdarlamasyna eki zhyl. [Two years to the program "Future Orientation: Spiritual Revival"].

https://ruh.kz/en/news/bolashakka bagdar_ruhani_zhangiru bagdarlamasina eki_zhil/

[5]. Omirtaj A. Tapsyrys - adebietke zhasalatyn qijanat. [Order is an abuse of literature]. https://tilalemi.kz/article/1627

[6]. Novikova M. G. The measure of meaning, actual division and the adequacy of translation: monograph. Moscow: Flint: Nauka, p. $2012-208$.

[7]. Kadirsheeva, A. Zh. Problems of translation of literary texts in Kazakh translation studies / A. Zh. Kadirsheeva. - Text : direct / / Young scientist. — 2021. — № 9 (351). — p. 235-237.

[8]. Sagyndykova N. Fundamentals of literary translation: a textbook. Almaty: Sanat, 1996. p. 208.

[9]. Zhaksylykov A. Zh. Actual problems of literary translation and the development of Kazakh literature: a textbook. - Almaty: Kazakh University, 2011. p. 136.

[10]. Alimov V. V., Artemyeva Yu. V. Literary translation: a practical course of translation. - Moscow: Publishing center "Academy", 2010, p. 256.

\section{Әдебиеттер:}

[1]. Ахметова А.Б. Аударма теориясы мен тәжірибесінің негіздері (қазақ және орыс тілдеріндегі) дәріс курсының оку-әдістемелік құралы. - Павлодар: ПМПИ, 2014. 90 б.

[2]. Темірболат А, Жүсіпова А., Шортанбаев Ш. «ХХІ ғасырдағы филология ғылымы: мәселелері мен болашағы» атты халықаралық ғылыми форум материалдары. - Алматы: «Қазақ университеті», 2014,180 б. [3]. Алдашева А. Аударматану ғылымының басты ұғым-түсініктері туралы // Аударматану (ғылымипрактикалық көмекші құрал). Құраст.: Құлманов С. - Алматы:«Тіл»оқу-әдістемелікорталығы, 2008. - 26 б. [4]. Бөкенбайқызы Б. “Болашаққа бағдар: Рухани жаңғыру” бағдарламасына екі жыл. https://ruh.kz/kz/news/bolashakka_bagdar_ruhani_zhangiru_bagdarlamasina_eki zhil/

[5]. Өміртай А. Тапсырыс - әдебиетке жасалатын қиянат. https://tilalemi.kz/article/1627

[6]. Новикова М. Г. Мағынаның өлшемі, өзекті бөлу және аударманың жеткіліктілігі: монография. — М.: Флинта: Ғылым, 2012. - 208 б.

[7]. Кадиршеева, А. Ж. Қазақстандық аударма ғылымындағы көркем мәтіндерді аудару мәселелері / А. Ж. Кадиршеева. — - Мәтін: тікелей / Ж Жас ғалым. - 2021. — № 9 (351). — Б.235-237.

[8]. Сағындықова Н.көркем аударма негіздері: оқу құралы. Алматы: Санат, 1996.-208 Б.

[9]. Жақсылықов А. Ж. Көркем аударманың өзекті мәселелері және қазақ әдебиетінің дамуы: хрестоматия. Алматы: Қазақ университеті, 2011. - 136 б.

[10]. Алимов В. В., Артемьева Ю. В.Көркем аударма: практикалық аударма курсы. — М.: "Академия" баспа орталығы, 2010. - 256 б.

\section{Литература:}

[1]. Ахметова А.Б. Основы теории и практики перевода (казахского и русского языка) учебно-методическое пособие к лекционному курсу. - Павлодар: ПГПИ, 2014. - 90 С.

[2]. Темирболат А., Жусупова А., Шортанбаев Ш. «Филологическая наука в XXI веке: проблемы и перспективы» материалы научного форума. - Алматы: "Казахский университет", 2014. - 180 С.

[3]. Алдашева А. О главных понятиях переводоведческой науки // // Переводоведение (научно-практическое пособие). Сост.: Кулманов С.-Алматы: учебно-методический центр»Тіл", 2008. - 26 С.

[4]. Букенбаевна Б. "Взгляд в будущее: модернизация общественного сознания" 
в программе два года.

https://ruh.kz/kz/news/bolashakka_bagdar_ruhani_zhangiru_bagdarlamasina_eki

zhil/

[5]. Омиртай А. Заказ-злоупотребление литературой. https://tilalemi.kz/article/1627

[6]. Новикова М. Г. Мера смысла, актуальное членение и адекватность перевода: монография. - М.:

Флинта: Наука, 2012. — 208 c.

[7]. Кадиршеева, А. Ж. Проблемы перевода художественных текстов в казахстанском переводоведении / А.

Ж. Кадиршеева. - Текст : непосредственный // Молодой ученый. — 2021. — № 9 (351). — С. $235-237$.

[8]. Сагындыкова Н. Основы художественного перевода: учебное пособие. Алматы: Санат, 1996.-208 с.

[9]. Жаксылыков А. Ж. Актуальные проблемы художественного перевода и развитие казахской литературы: хрестоматия. - Алматы: Қазақ университеті, 2011. - 136 с.

[10]. Алимов В. В., Артемьева Ю. В. Художественный перевод: практический курс перевода. - М.:

Издательский центр «Академия», 2010. - 256 с. 